International Journal of Agriculture, Environment and Bioresearch

Vol. 5, No. 03; 2020

ISSN: 2456-8643

\title{
STORAGE CONTAINERS OF GRAPES IN THE REFRIGERATOR AND THEIR IMPACT ON THE QUALITY OF PRODUCTS
}

\author{
Sokhib Yakhshibekovich Islamov ${ }^{1}$, Sunnat Abdurakhimovich Jalalov ${ }^{2}$ and Jafar Abdusalimovich Shamshiev ${ }^{3}$ \\ ${ }^{1}$ Doctor of Agricultural Sciences, Professor of the Department Department of Storage and Reprocessing of \\ Agricultural Products, Tashkent State Agrarian University, Tashkent, Uzbekistan \\ ${ }^{2}$ USAID value Chain Development Project Specialist in Agriculture, Tashkent, Uzbekistan \\ ${ }^{3}$ Independent Researcher, Senior Teacher of the Department of Processing Agricultural Products, Jizzakh \\ Polytechnic Institute, Jizzakh, Uzbekistan
}

https://doi.org/10.35410/IJAEB.2020.5514

\begin{abstract}
In this article is given the information on the types of containers used in the process of storage of the grape variety Toyfi grown in different climatic conditions of the Republic in modern refrigerated enterprises, the materials, size, the average weight of the packaged raw material, the impact of packaged dishes on the quality indicators of the products, the shortcomings and advantages of the dishes in the storage process, and, the perspective types of containers due to their ecological peculiarities of materials.
\end{abstract}

Keywords: Grapes, crate, dynamics, exports, sea level, irrigation systems, cellulose, plastic.

\section{INTRODUCTION}

Today, more than 80 kinds of agricultural products grown in the Republic are exported to 66 countries of the world. With the increase in the volume and gross harvest of fruits and vegetables and grapes, it is becoming a topical issue to deliver them to consumers with high quality and without destruction. The total area of grapes grown in the world today is 74.5 million hectares; gross grape harvest is 77.8 million tons, of which grape fields in Uzbekistan are equal just to $1.5 \%$.

This is followed by the resolution of the president of the Republic of Uzbekistan dated October 23, 2019 "on approval of the strategy of the development of Agriculture of the Republic of Uzbekistan for 2020 - 2030 years"PF-5853 has defined measures for further improvement of the fruit and vegetable and viticulture Sector [1].

According to statistics of the World Bank, the total area of grapes grown in our Republic in 2019 was 110072 hectares, the total gross yield obtained from them amounted to 1767607 tons [1, 5]. At the same time, it is predicted that these figures will increase year by year, when the decisions and Orders adopted by our government are taken into account. 
It is known that the transmission of grapes grown throughout the year to consumers, based on morphological and biological indicators, chemical composition and quality indicators, is carried out in several ways.

Methods for delivering grown grapes to consumers depending on their chemical and quality indicators are presented (Table 1).

Table 1 .Methods of delivering grapes to consumers depending on their chemical and quality indicators

\begin{tabular}{|l|l|l|l|}
\hline $\begin{array}{l}\text { Biological } \\
\text { features }\end{array}$ & $\begin{array}{l}\text { Gross } \\
\text { yield, } \\
\boldsymbol{\%}\end{array}$ & $\begin{array}{l}\text { Methods of transfer to the } \\
\text { consumer }\end{array}$ & $\begin{array}{l}\text { Use in relation to the } \\
\text { mass of grown grapes } \\
\%\end{array}$ \\
\hline \multirow{2}{*}{$\begin{array}{l}\text { Grape varieties of } \\
\text { khuraki }\end{array}$} & 91,3 & Market counters and shops & 29 \\
\cline { 3 - 4 } & & Storage warehouses & 50 \\
\cline { 3 - 4 } Technical grapes & 8.7 & Processed products & 21 \\
\hline & $\begin{array}{l}\text { Wine products } \\
\text { products }\end{array}$ & 83 \\
\hline
\end{tabular}

As can be seen from the table above, a large $91,3 \%$ of grown grapes are considered to be horticultural varieties of grapes, they are sent mainly to the markets and shops or to foreign countries with a new break, in addition to 50\% to the cooling towers (temporary and modern cooling towers), more than $21 \%$ to the processing enterprises (drying, get juice and sauces). Another large part of the grapes, which is technique varieties, is considered to have the total amount of $8,7 \%$. Technical grape varieties are mainly used as in the production of wine, for $83 \%$, while the remaining waste from it as raw materials for the pharmaceutical industry (seed, shells), for $17 \%$.

It should be noted that today the increase the export potential of our Republic is carried out by storing grapes in modern warehouses.

The following Figure 1 shows the data on the export of agricultural products in the Republic today. 
Vol. 5, No. 03; 2020

ISSN: 2456-8643

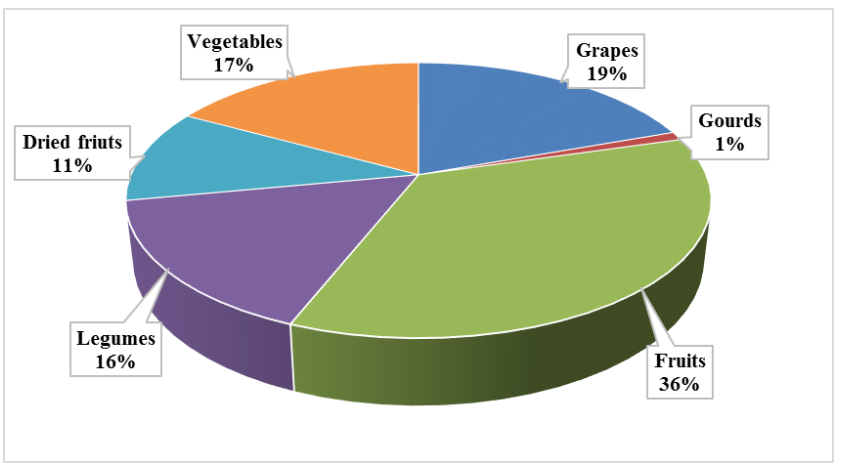

Figure 1. Dynamics of export of fruits and vegetables in the Republic in terms of 2018.

As can be seen from the picture, today more than $20 \%$ of grapes are exported from fruits and vegetables and other products exported from our Republic, the main part of which is fresh.

Therefore, each link in the supply of grape products to consumption and in the process will have to pay attention to its own specific factors aimed to improving the quality indicators of the product. One of such factors is the study of the types of grape packaging containers, their impact on the quality indicators of grapes, on the process of storage for a long period of time; there has not been enough research work in this direction in our Republic.

\section{MATERIALS AND METHODS}

One of the research tasks carried out by us was carried out in the districts of Zarkent of Tashkent region, Samarkand of Samarkand region, Bukhara of Bukhara region and Kitab of Kashkadarya region, which differ sharply from each other in different climatic conditions of the Republic weather, sea level, irrigation systems.

As an object of our research, the Toyfi grape variety was selected. Storage processes the influence of Toyfi grape varieties grown in the regions of the Republic on quality indicators in the processes of harvesting, packaging and storage of them in modern refrigerators has been studied. The picture below shows the dishes that are used in the process of storing grapes.

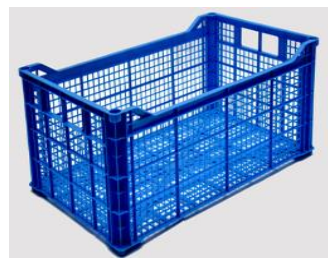

a

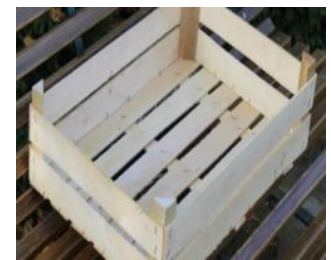

b

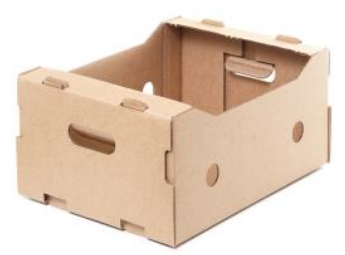

c

Figure 2. Types of dishes used for storing grapes.

The types of dishes that are used for the processes of grape storage today in our Republic are presented in Figure 2 above. Each of the dishes presented in the picture has its own advantages and disadvantages, that is, the crate shown in Figure 2a is made of plastic material, these types of dishes are widely used mainly in the southern regions of the Republic, another one (Figure $2 b$ ) is 
Vol. 5, No. 03; 2020

ISSN: $2456-8643$

made of local wooden materials and is widely used mainly in the Valley regions of the Republic, the third one (Figure 2c) is made of cellulose, and widely used in European countries, India and China. In this regard, it should be noted that the containers made of cellulose for the farmers and exporters- entrepreneurs of the Republic will serve as future packaging containers.

\section{RESULTS AND DISCUSSION}

At the next stage, in order to determine the advantages and disadvantages of the abovementioned plastic and wooden dishes, scientific research was conducted by us, the results of which are presented in the following Figure 3 - the packaging process and in the Table 1-the data obtained during the storage process.

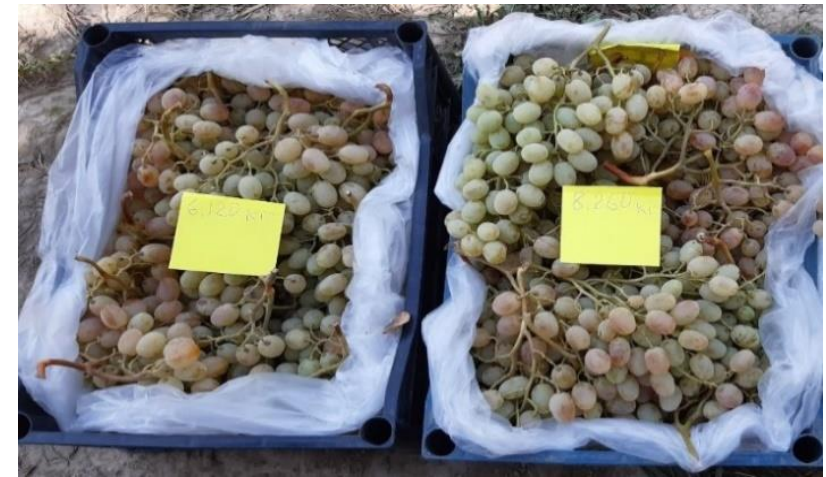

a) plastic

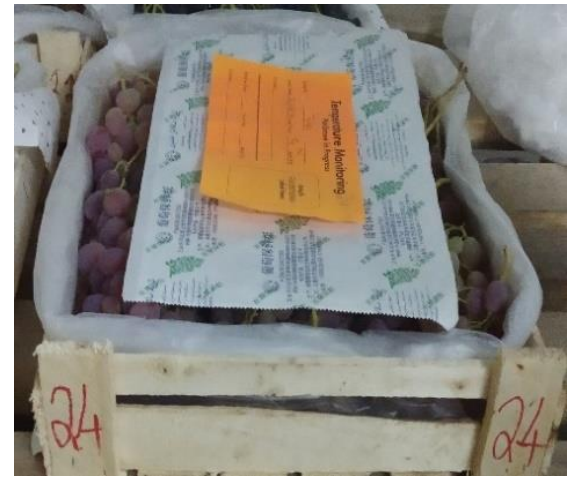

b) wood

Figure 3. The process of storage of grape variety Toyfi.

It should be noted that the process of packing the grape variety in various containers is presented in the results of our research on products that have been preserved in modern refrigerated containers from the beginning of September to the end of December of 2019.

Table 2 .The results of packing process of grape variety Toyfi in different containers

\begin{tabular}{|c|c|c|c|c|c|}
\hline Province & $\begin{array}{l}\text { Type of } \\
\text { container }\end{array}$ & $\begin{array}{l}\text { Weight of the } \\
\text { grape container } \\
\text { put on storage. on } \\
\text { average, } 4 \text { pieces } \\
\text { of pots are on } \\
\text { account } \\
\text { September, kg }\end{array}$ & $\begin{array}{l}\text { The weight of the } \\
\text { grape-packed } \\
\text { container after } \\
\text { storage. } \\
\text { average, } 4 \text { pieces } \\
\text { of pots are on the } \\
\text { account of } \\
\text { December, kg }\end{array}$ & $\begin{array}{l}\text { The difference } \\
\text { in the mass of } \\
\text { dishes in the } \\
\text { process of } \\
\text { storage is on } \\
\text { account of } \\
\text { December, gr }\end{array}$ & $\begin{array}{l}\text { On } \\
\text { account } \\
\text { of each } \\
\text { vessel, gr }\end{array}$ \\
\hline \multirow{2}{*}{ Tashkent } & Wood & 29.1 & 29.445 & 435 & 108 \\
\hline & Plastic & 33.509 & 33.189 & -320 & -80 \\
\hline Samarkand & Plastic & 27.4 & 27.15 & -250 & -62.5 \\
\hline Bukhara & Plastic & 33.639 & 33.29 & -349 & -87.25 \\
\hline Kitab & Plastic & 31.995 & 31.713 & -282 & -70.7 \\
\hline
\end{tabular}


Vol. 5, No. 03; 2020

ISSN: 2456-8643

According to the results of the research, as can be seen from the table, today in our Republic, mainly wood and plastic types of packaging containers are used for storage of grapes in refrigerators. According to the results, the average weight of grapes packed in each container was $6.5-8 \mathrm{~kg}$. It was observed that the quality of grapes in various containers packed and their organoleptic performance practically did not change. The weight of the product in the wooden crate, packed grapes, is increased to $108 \mathrm{gr}$, due to the wet pulling of the wooden material on the account of one container. If we take into account the fact that this figure is located approximately 10000 units of crate in the cooling capacity of 100 tons, it is $1080 \mathrm{~kg}$, then when multiplying $1080 \mathrm{~kg}$ to the market price of grapes, it in turn will bring additional income to the entrepreneur. But at the same time, in the opinion of experts, the wet pulling of wooden crates also leads to the development of micro-organisms. In the process of storing grapes in the second type of plastic containers, it was determined that the average reduction of $75 \mathrm{gr}$ from each crate. We believe that the reason is due to the natural reduction of grapes in the storage process.

\section{CONCLUSIONS}

Thus, as a result of the researches carried out, it was determined that in the process of storage of grapes in refrigerated containers in the Republic, mainly the use of wooden and plastic containers, as a result of their moisture content in wooden containers, increased container weight, while plastic containers decreased the total weight due to the decrease in the natural weight of grapes, and in recent years, the demand for packing containers, made by ecological standard, increased, as well as the demand for cellulose containers in the world grape-exporting countries.

\section{REFERENCES}

[1]Decree of the president of the Republic of Uzbekistan on "Additional measures for the deep processing of agricultural products and further development of the food industry” № PP-4406 dated 29.07.2019, www.lex.uz

[2]Buriev Kh. Ch, Juraev R.S, Alimov A. Storage of fruits and vegetables and their preliminary processing. Tashkent: "Labor", 2002.

[3]Mirzaev M.M. Ampelography of Uzbekistan. Tashkent: "Uzbekistan", 1984.

[4] Oripov R., Sulaymonov I, Umurzoqov E. Technology of storage and processing of agricultural products. Tashkent: "Labor", 1991.

[5]Fayziev J.N. The influence of growth regulators on the fertility of seedless tarnau sort. International journal of science and research (IJSR). Vol. 8, Iss. 1, pp. 1120-1122, 2019.

[6]Fayziev J.N.. Scientific justification of the technology of increasing the yield and quality of seedless varieties of grapes in the conditions of Uzbekistan. Thesis of dissertation doctor of agricultural sciences, Tashkent, 38 p., 2020. 